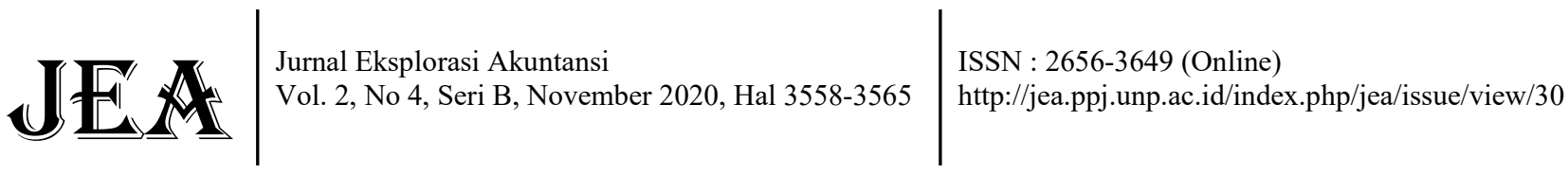

\section{PKM Usaha Dendeng Rinuak di KUB Dapur 21 Kenagarian Lubuk Basung Melalui Pelatihan Penyusunan Harga Pokok Produksi Dengan Metode Job Order Costing dan Inovasi Produk Makanan}

\author{
Halmawati $^{1}$, Lucy Fridayati ${ }^{2}$, Al Rafni ${ }^{3}$ \\ ${ }^{1}$ Jurusan Akuntansi Fakultas Ekonomi Universitas Negeri Padang \\ ${ }^{2}$ Jurusan IKK Fakultas Pariwisata dan Perhotelan Universitas Negeri Padang \\ ${ }^{3}$ Jurusan PPKN Fakultas Ilmu Sosial Universitas Negeri Padang \\ *Korespondensi: titianluthan@gmail.com
}

Abstract: Kegiatan pengabdian kepada masyarakat ini di latar belakangi oleh masalah yang dihadapi mitra yaitu usaha rinuak pada UKM Kelompok Usaha Bersama Dapur 21, yang merupakan kelompok mitra yaitu masyarakat yang aktif secara ekonomi yang bergerak dibidang produksi makanan tradisional yang berbasis sumber daya lokal. Dalam menjalankan usaha mereka terkendala oleh masih kurangnya pengetahuan dalam hal penyusunan Harga Pokok Produk dimana banyak biaya-biaya yang diperlukan dalam proses produksi namun tidak dimasukan dalam penghitungan biaya produk terutama terkait dengan Biaya Tenaga Kerja dan Biaya Overhead. Disamping itu produk yang dihasilkan kurang inovatif baik dari sudut rasa (taste, tampilan luar maupun proses pengolahan produk yang cendrung tidak variatif serta konvensional. Hal ini menyebabkan penentuan harga jual tidak sesuai dengan seharusnya serta kualitas produk kurang berkembang. Selain itu dampak covig 19 membuat usahawan semakin terpuruk sehingga perlu pemberian motivasi sehingga mereka mampu melewati dan bertahan dari kondisi ini

Keywords: KUB Dapur 21, Harga Pokok Produksi, Inovasi Produk

How to cite (APA $6^{\text {th }}$ style):

Halmawati, Fridayati, L; Rafni, A. (2020). PKM Usaha Dendeng Rinuak di KUB Dapur 21 Kenagarian Lubuk Basung Melalui Pelatihan Penyusunan Harga Pokok Produksi Dengan Metode Job Order Costing dan Inovasi Produk Makanan. Jurnal Eksplorasi Akuntansi, 2(4), Seri B, 3558-3565.

\section{PENDAHULUAN}

Perkembangan dunia usaha yang semakin mengairahkan serta perkembangan ekonomi global yang semakin meningkat dari kewaktu kewaktu menuntut masyarakat untuk semakin giat dan aktif dalam meningkatkan perekonomi keluarga. Peningkatan ekonomi masyarakat tidak hanya tanggungjawab pemerintah sebagai lembaga pemerintahan formal yang merupakan leader of public, namun juga dimulai dari keluarga sebagai unit terkecil dari masyarakat. 
Untuk meningkatkan pertumbuhan ekonomi, diperlukan sumberdaya manusia yang kompeten dan handal. Jumlah penduduk yang banyak namun tidak memiliki skill, akan berdampak buruk bagi suatu negara. Masalah ekonomi yang akan timbul seperti peningkatan jumlah pengangguran, lapangan kerja yang dikuasai tenaga kerja asing, produktivitas kerja yang buruk, dan sebagainya. Pertumbuhan ekonomi akan meningkat tajam apabila dibantu oleh sumberdaya manusia yang massif dan berkualitas. Keahlian mumpuni yang dimiliki para angkatan kerja di harapkan mampu mendongkrak perekonomian negara. Sebagai contoh para pengusaha dengan start up lokalnya yang membuka kesempatan kerja baru sehingga jumlah pengangguran akan semakin berkurang.

Kegiatan untuk membangun ekonomi tentunya dimulai dari kegiatan dari unit yang terkecil dari organisasi pemerintahan yaitu dimulai dari pembangunan pedesaan yang tidak hanya terbatas hanya pada pembangunan infrastruktur, melainkan juga pengembangan terhadap sumber daya alam dan sumber daya manusianya. Hal ini terlihat dari banyaknya program pemerintah untuk mengembangkan ekonomi pedesaan berbasis pemberdayaan pada sumber daya manusia untuk mengoptimalkan potensi sumber daya manusia dan sumber daya alamnya. Salah satu sektor yang didorong yaitu usaha kecil dan menengah (UKM).

Jaidan (2010) mengemukakan bahwa usaha kecil dan menengah (UKM) merupakan salah satu bidang yang memberikan kontribusi yang signifikan dalam memacu pertumbuhan ekonomi Indonesia. Hal ini dikarenakan daya serap UKM terhadap tenaga kerja yang sangat besar dan dekat dengan rakyat kecil. Dinas Koperasi dan UKM Provinsi Sumatera Barat (2017) menyebutkan bahwa pembangunan Koperasi dan UKM saat ini juga diarahkan untuk memperkuat peningkatan kontribusi UKM dalam perekonomian, baik dalam penanggulangan kemiskinan, penciptaan lapangan kerja maupun dalam peningkatan nilai tambah perekonomian yang menyokong pertumbuhan ekonomi yang tinggi dan pembangunan yang berkelanjutan.

UKM yang ada di Indonesia masih menghadapi berbagai masalah antara lain masalah promosi, pemasaran, penjualan produk yang dihasilkan serta masyarakat belum dapat mengoptimalkan potensi yang ada di wilayahnya dan masyarakatnya. Dalam menjalankan perannya sebagai titik tumpu penyokong perekonomian, UKM juga menghadapi berbagai masalah yang menyebabkan perkembangannya terhambat. Permasalahan klasik pada UKM di Sumatera Barat saat ini dapat dikelompokkan dalam dua kategori, yakni masalah-masalah internal dan masalah-masalah eksternal. Masalah-masalah internal pada UKM antara lain adalah kesadaran dan kemauan pengusaha untuk menerapkan ilmu pengetahuan dan teknologi tepat guna di usaha masih sangat terbatas, keterbatasan modal untuk melakukan perbaikan/peningkatan teknologi, ketidakmampuan mengukur kinerja dengan konsep biaya yang seharusnya, kurangnya kemampuan pengusaha untuk memanfaatkan peluang usaha, lemahnya akses serta terbatasnya informasi tentang teknologi dan pengetahuan tertentu.

Sedangkan masalah-masalah eksternal pada UKM adalah sebagian besar hasil litbang yang ada hingga saat ini bukan yang diperlukan oleh UKM, proses alih teknologi kepada UKM belum optimal, antara lain keterbatasan tenaga pendamping di lapangan, publikasi hasil-hasil litbang masih terbatas dan penyebarannya belum menjangkau UKM di seluruh wilayah, skim pembiayaan untuk pengembangan ilmu pengetahuan dan teknologi termasuk pembelian mesinmesin baru untuk UKM masih terbatas. Ditambah lagi dengan masalah yang saat ini melanda dunia yaitu wabah Covid 19 yang cukup berdampak pada seluruh sektor kehidupan, termasuk UKM yang menjadi penyokong ekonomi terbesar bangsa.

Salah satu UKM yang banyak anggotanya yaitu KUB Dapur 21, yang berada di Jorong Surabayo, Kenagarian Lubukbasung, Kecamatan Lubukbasung yang berada di Kabupaten Agam. Kenagarian Lubukbasung ini, memiliki beragam potensi baik dari segi sumber daya alam 
maupun sumber daya manusianya., Karena secara secara geografis kenagarian Lubukbasung ini berdekatan dengan danau maninjau, yang memiliki sumber daya alam yang banyak . Adapun jarak tempuh kecamatan Lubukbasung dan Tanjung Raya lebih kurang 17,3 km atau sekitar 15 menit dari kota Lubukbasung dengan tranportasi darat. Adapun mata pencaharian utama masyarakat adalah petani, pengrajin makanan/kuliner, PNS dan wiraswasta.

UKM KUB Dapur 21 di Kota Lubukbasung adalah UKM yang bergerak diusaha makanan/kuliner, dengan berbagai macam produk usaha makanan yang dihasilkan,dimana beberapa usahanya yang terkenal adalah Usaha Dendeng Rinuak, Rendang Paku dst. Berdasarkan wawancara dengan pimpinan usaha Dapur 21 (Maret 2020) dapat diketahui bahwa UKM KUB Dapur 21, beranggotakan 21 orang pelaku usaha makanan. Mereka melakukan pertemuan secara berkala di KUB Dapur 21 tersebut untuk mendiskusikan tentang berbagai jenis produk makanan yang sedang trend saat ini, inovasi produk, pengemasan serta pemasaran produk.

Pada umumnya ibu-ibu dan remaja putri melakukan pekerjaan usaha kuliner tersebut sebagai kegiatan sampingan untuk menambah income keluarga. Namun dalam menjalankan usaha, pelaku usaha makanan tersebut terkendala oleh kurangnya pengetahuan dan keterampilan dalam menentuka harga pokok dari produk yang dihasilkan. Selama ini mereka berproduksi tanpa ada pedoman yang jelas dalam mengelompokan biaya produksi yang dikeluarkan dalam proses produksi yang terjadi, bahkan biaya tebaga kerja yang seharusnya masuk dalam proses produksi yang mereka lakukan tidak dihargai sama sekali serta biaya pendukung lainnya (biaya overhead) tidak memenuhi kaidah biaya produksi yang seharusnya. Ketiadaan skill dalam menghitung cost production tersebut menyebabkan mereka dalam menentukan harga jual tidak sesuai dengan konsep laba rugi yang seharusnya sehingga berdampak pada perkembangan usaha yang tidak memberikan hasil yang setimpal. Disamping itu produk yang dihasilkan tidak mempunyai variasi dan cendrung monoton sehingga perlu juga pengembangan inovasi produk baik dari segi rasa (taste), bentuk tampilan, warna, teknik dan jenis produk sehingga kualitas produk kurang berkembang. Ditambah lagi dimasa pandemi covid 19 saat ini yang cukup berdampak pada pemasaran dimana sulitnya pemasaran produk. Untuk itu pelaku usaha perlu strategi pemasaran dan manajemen usaha yang lebih baik agar ekonomi ppelaku usaha makanan ini kembali bangkit dan pulih.

Dilihat dari prospeknya, usaha makanan ini cukup menjanjikan untuk meningkatkan ekonomi rumah tangga, yang mana Sumatera Barat merupakan salah satu daerah tujuan wisata, baik wisatawan lokal maupun manca negara yang memungkinkan untuk pemasaran produkproduk yang punya ciri khas rasa makanan yang mengundang selera dan juga merupakan produk makanan yang khas seperti dendeng rinuak yang hanya ada di daerah Kab Agam/Kota Lubukbasung, dengan ciri ikan kecil species ikan rinuak yang hanya ada di Danau Maninjau. Dengan berkembangnya Sumatera Barat sebagai salah satu daerah tujuan parawisata, maka diharapkan makanan yang merupakan ciri khas ranah minang ini disukai oleh para wisatawan maupun perantau yang pulang kampug sebagai oleh-oleh makanan khas Lubukbasung, Kab Agam.

Berdasarkan uraian di atas maka perlu dilakukan kegiatan pembinaan dan pembekalan keterampilan kepada pelaku usaha kuliner dan masyarakat baik mengenai penentuan harga pokok produk yang nantinya penting sekali dalam penentuan harga jualnya produk serta peningkatan kualitas produk baik dari segi rasa, bentuk/tampilan, warna, teknik dan jenis produk serta strategi pemasaran dan manajemen usaha yang lebih baik. Melalui kegiatan pengabdian kepada masyarakat oleh perguruan tinggi, dalam hal ini UNP diharapkan dapat 
membantu pelaku usaha makanan ini dalam mengatasi kendala-kendala yang dihadapi dan juga diharapkan dapat meningkatkan income mereka khususnya.

\section{METODE PELAKSANAAN}

Pada kegiatan ini, tim menggunakan beberapa jenis metode untuk menyelesaikan masalah, yaitu

1) Analisis Kebutuhan dan Identifikasi Masalah

Tahap awal dari kegiatan ini adalah mencari permasalahan utama yang dihadapi oleh tempat mitra. Dengan melakukan diskusi dan koordinasi dengan Wali Nagari Kenagarian Lubukbasung, jorong surabayo, diketahui permasalahan apa yang tengah dihadapi oleh pelaku usaha UMKM KUB Dapur 21 di Kenagarian Lubukbasug. Dari wawancara yang dilakukan ditemukan pokok masalah bahwa UMKM KUB Dapur 21 Lubukbasung, mengalami kesulitan dalam menghitung Harga Pokok Produksi serta kurangnya inovasi dalam pengolahan produk berbahan dasar rinuak, yang selama ini produk yang dibuat terkesan monoton

2) Memberikan pemaparan materi dan diskusi

Metode ini digunakan untuk memberikan materi tentang bagaimana cara menyusun Harga pokok produksi yang seharusnya karena selama ini pelaku usaha tidak memiliki catatan atau tidak pernah menghiting biaya terkait produksi yang mereka lakukan, sehingga penetapan harga jualpun tidak mengunakan data yang akurat. sebagai solusi atas permasalahan ini pelaku usaha UMKM Dapur 21 , diberikan kertas kerja untuk meyusun harga pokok produksi yang bisa menjadi pedoman dalam proses pengitungan harga pokok yang tepat. Disamping itu pelatihan juga diberikan paparan terkait peranan UMKM dalam nagari serta estetika dalam proses memasak yang seharusnya, sebagai basic dalam praktikum meamasak terkait inovasi produk berbahan dasar rinuak .

3) Praktek terbimbing

Setelah diberikan pemaparan materi, peserta akan dibagi ke dalam beberapa kelompok yang beranggotakan 4-5 orang. Masing-masing kelompok diberikan tugas untuk mempraktekan cara mengolah produk berbahan dasar rinuak dan Narasumber akan memberikan bimbingan dan fasilitas selama proses praktek terbimbing berlangsung.

4) Monitoring dan Evaluasi

Pada tahap ini perserta dan fasilitator melakukan refleksi dan evaluasi terhadap hasil pelatihan yang telah diberikan.

\section{HASIL DAN PEMBAHASAN Kegiatan Pendidikan dan Pelatihan}

Kegiatan pendidikan masyarakat ini dilakukan dalam bentuk pemberian pelatihan mengenai penyusunan harga pokok produksi dengan metode job order costing. Penyusunan harga pokok produksi ini penting diberikan pada pelaku usaha UMKM Dapur 21,karena selamai ini mereka melakukan proses produksi tidak ada menghitung berapa biaya produksi yang telah dikeluarkan, bahkan ada biaya biaya yang seharusnya amereka keluarkan namun tidak ada diperhitungkan sebagai bagian dari biaya produksi, antara lain biaya tenaga kerja yang mereka sumbangkan sebagai diri mereka sendiri yang melakukan pengolahan produk, biaya bahan penolongnya yang men support produksi, serta beban air dan listrik yang terpakai dalam proses pengolahan juga tidak diakui dllnya. Pelatihan yang diberikan bisa dijadikan solusi bagi pelaku usaha untuk bisa mengukur kinerja mereka secara lebih tepat dengan adanya transfer ilmu terkait diatas bisa sehingga kinerja mereka secara lebih valid bisa 
dihitung dalam menetapkakan harga jual yang pantas serta menghitung laba mereka kelak
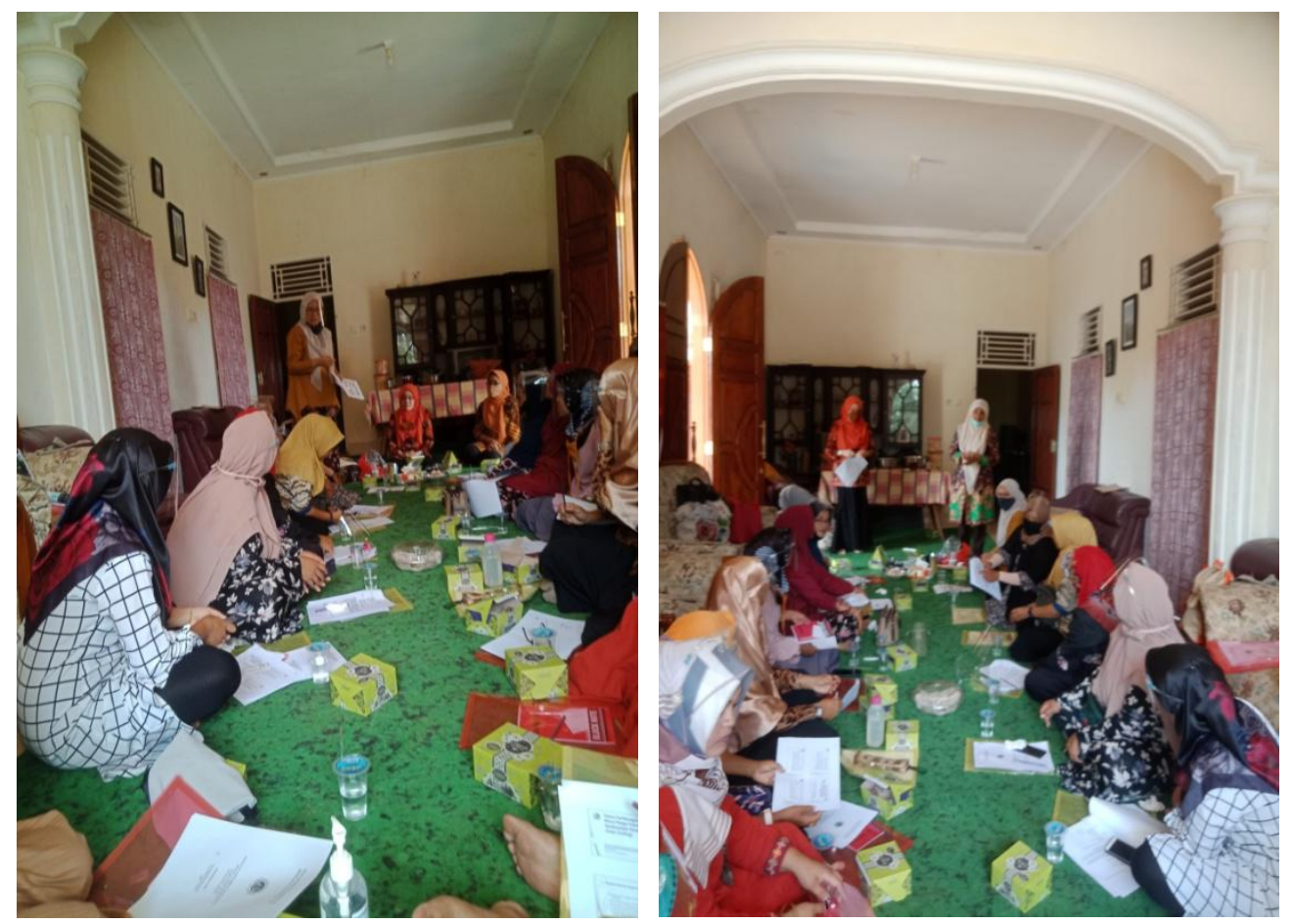

Gambar 1, acara pemberian pelatihan terkait harga pokok produksi dan inovasi produk makanan di Lubukbasung

Pada kegiatan ini para peserta UMKM Dapur 21 dibekali pemahaman dan penjelasan mengenai perlu dan pentingnya proses penyusunan harga pokok produksi serta manfaat perlunya catatan keuangan dalam proses pproduksi yang seharusnya serta estetika dalam tata boga, teknik memasak, pengenalan alat dan resep serta penyajian dari hasil produk. Kegiatan pelatihan ini mendapat respon yang sangai baik dari peserta, hal ini terlihat dari besarnya rasa kaingintahuan dari para pelaku usaha dengan banyaknya pertanyaan yang diajukan.

Transfer pengetahuan terkait biaya produksi ini diawali dengan pengenalan terhadap konsep biaya produksi, jenis jenis biaya dan cara penyusunan harga pokok produksi (job order costing), penerapan metode job order costing penting dilakukan karena produk dendeng rinuak yang dibuat ini di produksi berdasarkan pesanan dari konsumen. Konsep biaya penting diberikan karena mengetahui pemahaman terhadap konsep biaya peserta nantinya diharapkan bisa membedakan mana pengeluaran yang dianggap sebagai biaya (barang modal) ataupun mana pula yang dikatakan sebagai beban yang sudah habis manfaatnya saat kita mengeluarkan sejumlah uang tersebut, dalam hal ini pemahaman terkait konsep ini akan membantu mereka dalam menghitung beban produksi (biaya produksi) yang dapat mereka perhitungkan dalam menghitung cost production.

Hal yang sama juga dapat diberikan transfer ilmu terkait pengenalan biaya produksi, yang mana tidak semua biaya bisa diklasifikasikan sebagai biaya produksi, namun harus bisa memilah mana yang dikatakan biaya produsi, yaitu biaya yang terkait proses pengolahan bahan baku menjadi barang jadi (dendeng rinuak) sehingga biaya diluar tersebut bisa diklasifikan sebagai biaya pemasaran ataupun biaya administrasi dan umum. Selain itu dalam proses inovasi produk berbahan dasar rinuak juga diberikan pengetahuan terkait pengenalan 
terhadap objek bahan mentah yang akan diolah, karena ketidak tahuan karakteristik jenis ikan yang diolah akan menghasilkan produk yang tidak maksimal serta merusakcitarasa ciri khas dari rinuak tersebut.

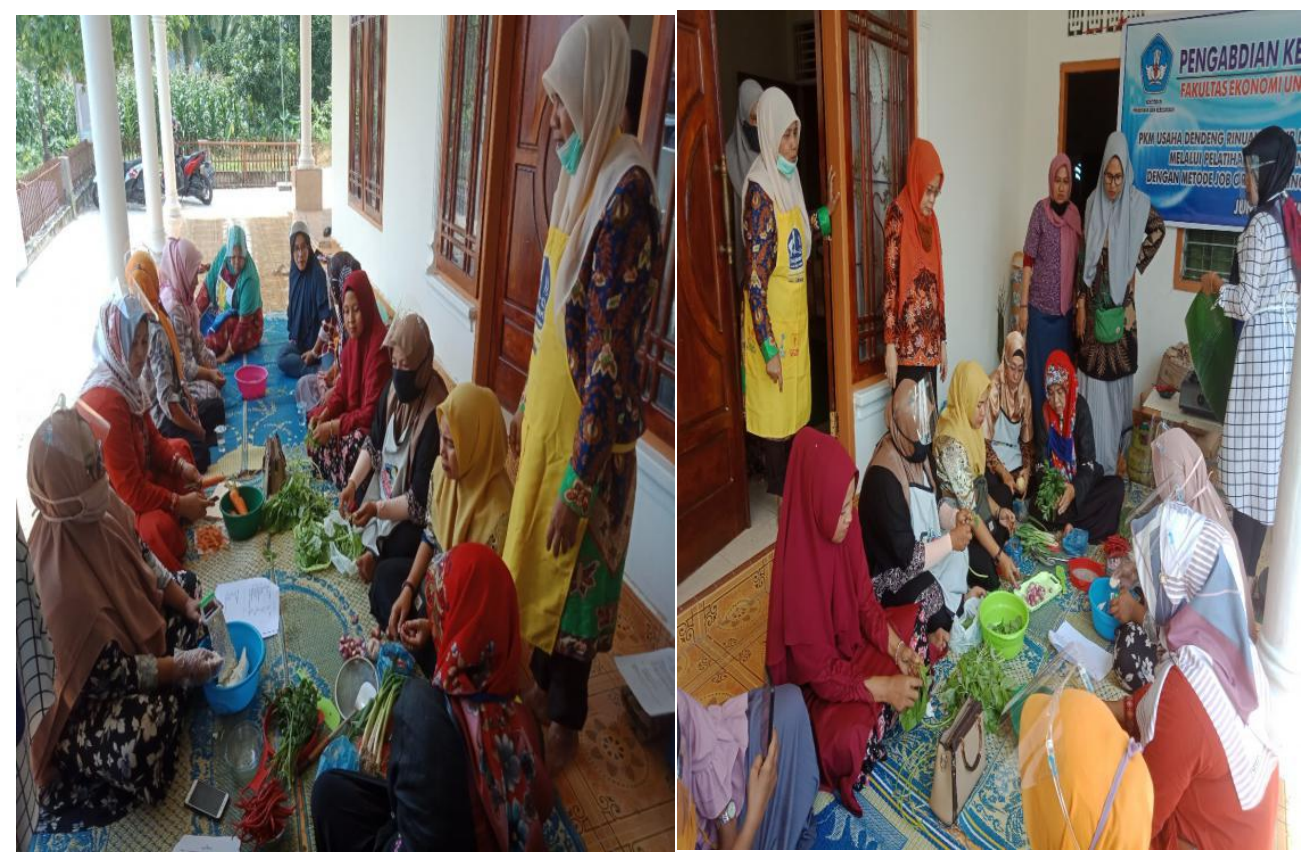

Gambar 2, Acara pemberian pelatihan terkait harga pokok produksi dan inovasi produk makanan di Lubukbasung

Pelaku usaha KUB Dapur 21 sangat antusias mengikuti kegiatan pelatihan tentang teknik penyusunan harga pokok produk dan inovasi produk berbahan dasar rinuak ini, dimana dalam kegiatan PKM ini telah dihasilkan 3 jenis produk inovasi baru yang menjadi objek dalam kegiatan PKM ini dengan bahan dasar rinuak . Beberapa macam jenis produk tersebut antara lain : rinuak singkong (risi), bakso rinuak tertawa (Bakri), stick rinuak. Adapun rinuak ini adalah jenis ikan berukuran sangat kecil yang merupakan salah satu ikan ciri khas dari Danau Maninjau yang mudah didapat di daerah lubuk basung yang berdekatan dengan Danau Maninjau sebagai sentra penghasil rinuak.

Adapun rinuak ini mudah didapat dan harganya pun cendrung terjangkau sehingga ini bisa menjadi komoditi dan peluang usaha bagi UMKM di Lubukbasung untuk mengembangkan bisnis makanan dari bahan dasar rinuak ini. Dengan kemampuan dalam menghitung biaya produksi dengan lebih handal akan membantu pelaku usaha dalam menghitung progress kinerja keuangan mereka dan ini akan menjadi peluang usaha yang potensial bagi masyarakat khususnya UMKM KUB Dapur 21 dan UMKM lainnya dalam menjalankan roda bisnis walaupun tenggah dihadap wabah covid ini 

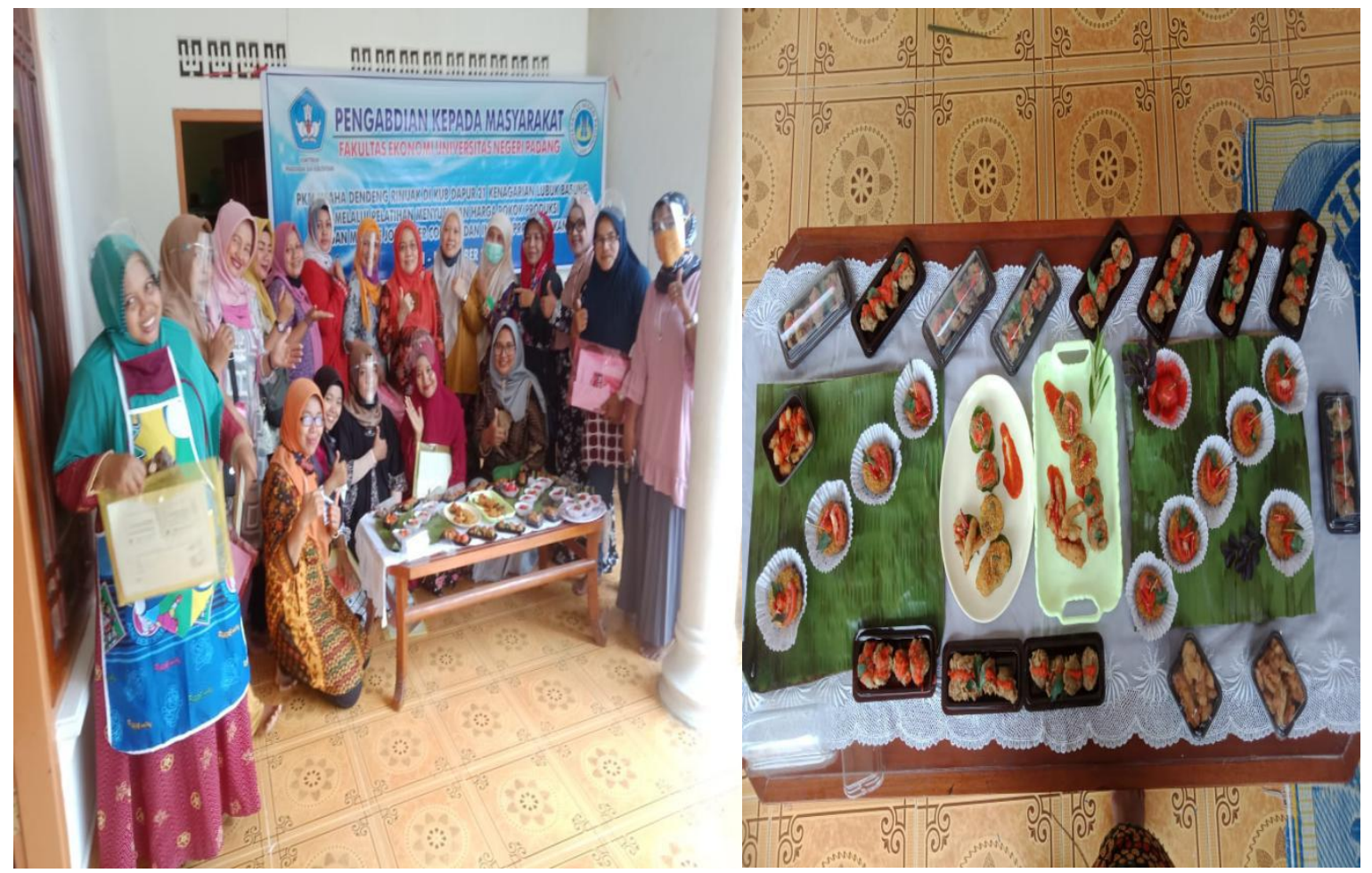

Gambar 3, acara pemberian pelatihan terkait harga pokok produksi dan inovasi produk makanan di Lubukbasung

\section{KESIMPULAN}

Pemberian pelatihan penyusunan harga pokok produksi dan inovasi produk telah dilakukan di Kenagarian Lubukbasung untuk mengatasi permasalahan yang dialami oleh pelaku usaha UMKM KUB Dapur 21. Kekurangpahaman dan ketidakmampuan dalam menyusun harga pokok produksi sering membuat pelaku usaha khususnya UMKM KUB Dapur 21 tidak bisa menentukan harga pokok produksi dendeng rinuak yang dihasilkannya secara tepat dan hal ini berimbas pada penetapan harga jual yang tidak valid, sehingga dengan adanya kegiatan PKM ini bisa menjawab semua permasalahan tersebut dan penetapan harga pokok bisa dihitung secara akurat.

Demikian juga dengan adanya inovasi produk berbahan dasar rinuak, dimana kedepannya pelaku usaha lebih percaya diri dan semakin inovatif, dengan sudah dihasillkannya tiga jenis produk dengan kreasi baru, diharapkan ini bisa sebagai langkah awal serta modal dasar bagi pelaku usaha untuk lebih kreatif dan inovatif dalam berproduksi sehingga peningkatan ekonomi bisa dirasakan lebih baik dari sebelumnya. Dan Kabupaten Agam sebagai daerah tujuan parawisata bisa semakin banyak dikunjungi para pelancong baik lokan maupun dari manca negara, dengan membawa oleh oleh makanan dari produk bernahan dasar rinuak sebagai ciri khas kabupaten Agam-Lubukbasung .

\section{UCAPAN TERIMA KASIH}

Terima kasih disampaikan kepada Rektor Universitas Negeri Padang yang sudah memfasilitasi pembiayaan PKM-PNBP 2020 dan terima kasih juga disampaikan kepada pemerintahan Kabupaten Agam, terkhusus kepada Pemerintahan Nagari Lubukbasung dan Peserta Dapur 21 Lubukbasung yang telah berpartisipasi dalam kegiatan ini. 


\section{DAFTAR RUJUKAN}

Alma, B. 2004. Kewirausahaan.Alfabeta. Bandung.

Dinas Koperasi dan UKM Provinsi Sumatera Barat. 2017

Busharmaidi. 2007. Pengembangan UKM Sumatera Barat. Padang : Litbang Sumbar

Hafsah, M.J. 2004. Upaya Pengembangan Usaha Kecil dan Menengah (UKM).

Jurnal Infokop Nomor 25 Tahun 2004

Hansen, Mowen, 2003, Cost Management, 4 th edition, South Western, Ohio

Jaidan Jauhari, 2010. Upaya Pengembangan Usaha Kecil Dan Menengah (Ukm) Dengan Memanfaatkan E-Commerce, Jurnal Sistem Informasi (JSI), VOL. 2, NO. 1, April 2010

Kastaman, Roni. 2009. Pemasaran Untuk Produk Cemilan Industri Rumah Tangga . Lokakarya Pemecahan Masalah di Sentra Makanan Kota Bandung.

Lawrence H. Hammer, William K. Carter \& Milton F Usry, 1977, Cost Accounting, 11 th editions, South Western Publishing, Co, Ohio.

Mulyadi, 2003, Akuntansi Manajemen, edisi ketiga, Yogyakarta, BPFE STIE YKPN

Mulyadi, 2001, Akuntansi Manajemen, edisi ketiga, Jakarta. Salemba Empat

Sunarto 2003, Akuntansi Biaya, Edisi Revisi, Yogyakarta: Amus Yogyakarta \& Mahenoko, Total Design Yogyakarta

Supriyono, 19999, Akuntansi Manjemen, Konsep Dasar Akuntansi Manajemen dan Proses Perencanaan, Cetakan kelima, Yogyakarta; BPFE UGM

Suryana. 2001. Kewirausahaan. Salemba Empat. Jakarta. 